Vol. 4 No. 2 Tahun 2020

ISSN 2580-5029

\title{
Potensi Ekstrak Lengkuas (Alpinia Purpurata K. Schum) Sebagai Fungisida Terhadap Jamur Alternaria Sp. Pada Tanaman Jeruk
}

\author{
Mia Nurkanti ${ }^{*}$, Mimi Halimah ${ }^{2}$, Yosi Silfister ${ }^{3}$, Handi Suganda ${ }^{4}$ \\ 1Universitas Pasundan1, Bandung, Indonesia \\ *mia.nurkanti@unpas.ac.id
}

\begin{abstract}
Alternaria sp. is one the causess of diseases that attack citrus crops. Pest and diseases control efforts by farmers more often use pesticide synthesis. This study aims to determine the inhibition of mushroom growth and other benefits of galangal extract as a natural fungicide and determine the optimum concentration of galangan extract inhibiting the growth mushroom of Alternaria sp.. The method used was experimental, testing conducted by growing mycelium mushroom Alternaria sp. on a PDA that has been mixed with extract of galangal in according to the respective concentrations and analyze growth response by measuring the diameter. The best results indicated by the treatments $60 \%$ that control the growth of mushrooms with deaths amounted to $79 \%$. This shown that galangal extract is able to control the growth of Alternaria sp. at concentrations $60 \%$ compared to a concentration of 20\%, 30\%, 40\% and 50\% because the active compounds at concentrations that are 60\% higher, so galangal extract diffuse into the cell the growing of mushrooms and may cause disruption the growth mushrooms Alternaria sp.. The higher concentration of extract given, the ability to controlling the growth mushroom of Alternaria sp. the better. The utilization of galangal material is done as an alternative fungicide in the control of plant diseases that are eco friendly.
\end{abstract}

Keywords:Alternaria sp., fungicides, galangal(Alpinia purpurata K. Schum)

\begin{abstract}
ABSTRAK
Alternaria sp. merupakan salah satu penyebab penyakit yang menyerang tanaman jeruk. Upaya pengendalian hama dan penyakit oleh petani lebih sering menggunakan pestisida sintetis. Tujuan penelitian ini untuk mengetahui penghambatan pertumbuhan jamur dan manfaat lain dari ekstrak lengkuas sebagai bahan fungisida alami dan untuk mengetahui konsentrasi optimum dari ekstrak lengkuas dalam menghambat pertumbuhan jamur Alternaria sp. Metode yang digunakan adalah eksperimen, pengujian dilakuakan dengan menumbuhkan miselium jamur Alternaria sp. pada PDA yang telah dicampur dengan ekstrak lengkuas sesuai dengan konsentrasi masing-masing dan menganalisa respon pertumbuhannya dengan mengukur diameter. Hasil terbaik ditunjukan oleh perlakuan 60\% yang mampu mengendalikan pertumbuhan jamur dengan kematian jamur sebesar 79\%. Hal ini menunjukan bahwa ekstrak lengkuas mampu mengendalikan pertumbuhan Alternaria sp. pada konsentrasi $60 \%$ dibandingkan dengan konsentrasi $20 \%, 30 \%, 40 \%$, dan 50\% karena pada senyawan aktif yang berada pada konsentrasi $60 \%$ lebih tinggi, sehingga ekstrak lengkuas yang berdifusi ke dalam sel jamur semakin meningkat dan dapat menyebabkan terganggunya pertumbuhan jamur Alternaria sp. Semakin tinggi perlakuan konsentrasi ekstrak yang diberikan, maka kemampuan mengendalikan pertumbuhan jamur Alternaria sp. semakin baik. Pemanfaatan bahan lengkuas dilakukan sebagai alternatif fungisida dalam pengendalian penyakit tanaman yang bersifat ramah lingkungan.
\end{abstract}


Kata Kunci: Alternaria sp., fungisida, lengkuas (Alpinia purpurata K. Schum)

\section{PENDAHULUAN}

Jeruk (Citrus sp.) merupakan salah satu komoditas buah unggulan nasional yang keberadaannya menyebar hampir di seluruh wilayah Indonesia. Tanaman jeruk termasuk tanaman yang mudah terserang hama dan penyakit sehingga petani merasa kesulitan mengendalikan hama dan penyakit tanaman jeruk. Salah satu penyakit yang biasanya menyerang pada tanaman jeruk ialah penyakit buah gugur prematur, penyakit ini menyerang bunga atau buah yang mempunyai gejala mula-mula tangkai buah membesar kemudian 2-4 minggu membusuk kering dan akhirnya sebelum panen buah akan gugur. Untuk pengendaliannya dengan cara menyemprotkan fungisida pada saat kuncup bunga mekar dan 2 minggu seterusnya. Upaya pengendalian hama dan penyakit secara terus menerus oleh kalangan petani sampai saat ini adalah lebih dominan menggunakan pestisida sintesis.

Peneliti ingin melakukan terobosan dalam mengatasi hama dan penyakit tanaman jeruk dengan menggunakan pestisida alami. Salah satu pestisida yang akan dicoba yaitu menggunakan lengkuas merah (Alpinia purpurata K. Schum). Lengkuas merah merupakan jenis tumbuhan umbi-umbian yang bisa hidup di daerah dataran tinggi maupun dataran rendah. Umumnya masyarakat memanfaatkannya sebagai campuran bumbu masak dan pengobatan tradisional.

Pemanfaatan lengkuas untuk masakan dengan cara mememarkan rimpang lengkuas kemudian dimasukan begitu saja ke dalam campuran masakan. Lengkuas yang merupakan fungisida dapat digunakan sebagai salah satu jenis pestisida untuk mengendalikan penyakit akibat jamur. Tujuan penelitian ini adalah untuk mengetahui penghambatan pertumbuhan jamur dan manfaat lain dari ekstrak lengkuas merah (Alpinia purpurata K. Schum) sebagai bahan fungisida alami,untuk mengetahui konsentrasi optimum dari ekstrak lengkuas dalam menghambat per-tumbuhan jamur Alternaria sp.

\section{METODE}

Metode penelitian yang diterapkan pada penelitian ini adalah metode eksperimental. Metode eksperimen yaitu metode penelitian yang digunakan untuk mencari pengaruh perlakuan tertentu terhadap yang lain dalam kondisi yang dikendalikan (Sugiyono 2016).

Metode yang digunakan dalam penelitian ini menggunakan metode eksperimen. Penelitian ini juga menggunakan desain Rancangan Acak Lengkap (RAL) dengan tiga pengulangan dan delapan perlakuan. Perlakuan yang digunakan dengan taraf konsentrasi 20\%, 30\%, 40\%, 50\% 
Perubahan yang diamati selama, 60\%, 70\%, 80\% dan kontrol berupa PDA tanpa diberikan ekstrak lengkuas sebagai pembanding.

Perubahan yang diamati selama proses perubahan yaitu diameter tumbuh yang diukur dari pusat inokulum hingga lingkaran luar yang dilakukan pada pengamatan hari kelima. Persentase penghambat pertumbuhan dhitung menggunakan rumus seperti:

$$
R=\frac{R 1-R 2}{R 1} X 100 \%
$$

Keterangan:

R: Presentase penghambatan pertumbuhan (\%)

R1: Diameter pertumbuhan pada kontrol (mm)

R2: Diameter pada tiap perlakuan (mm)

Data yang diperoleh dari hasil penelitian kemudian dianalisis untuk mengetahui signifikansi perbedaan rerata dengan Analysis of Variance (ANOVA) oneway dan diuji lanjutan menggunakan Tukey dengan tingkat kesalahan yang digunakan adalah 5\% untuk mengetahui pengaruh perlakuan yang diujikan pada bahan.

Penelitian ini dilakukan di laboratorium Mikrobiologi Program Studi Pendidikan Biologi Universitas Pasundan Bandung, yang dilaksanakan pada periode bulan Mei-Juni 2017.

Penelitian dilakukan dengan mempersiapkan alat dan bahan yang diperlukan terlebih dahulu yang meliputi sterilisasi alat dan mempersiapkan bahan (isolat murni Alternaria sp., PDA dan ekstrak lengkuas). Melakukan penyortiran segar dengan cara membersihkan rimpang lengkuas meng-gunakan air bersih hingga terpisah dari sisa-sisa tanah, rimpang lengkuas yang masih segar sebanyak $2 \mathrm{~kg}$ dipotong-potong menggunakan pisau, potongan lengkuas dikeringkan kemudian diekstrak dengan cara maserasi. Alat-alat dan bahan yang akan dipakai pada saat penelitian harus melewatkan tahapan sterilisasi terlebih dahulu dengan menggunakan Autoclave selama 15-20 menit.

Menyiapkan PDA dan menimbangnya sebanyak 40 gram, tuangkan pada labu elemeyer, siapkan aquades sebanyak $1000 \mathrm{ml}$ yang telah diukur menggunakan gelas ukur, campurkan PDA dengan aquades. Panaskan dan aduk dengan menggunakan strirer. Media tumbuh perlakuan disiapkan dengan cara mencampurkan larutan ekstrak dengan PDA cair sesuai dengan taraf konsentrasi dalam cawan petri. Konsentrasi yang digunakan dalam penelitian ini adalah 20\%, 30\%, 40\%, $50 \%, 60 \%, 70 \%, 80 \%$ dan kontrol.

Media tumbuh perlakuan yang tersedia distrelilkan dengan menggunakan autoclave dengan suhu $121^{\circ} \mathrm{C}$ dan tekanan 1 atmosfer selama 15 menit. Setelah itu melakukan dengan menumbuhkan miselium jamur Alternaria $s p$. pada media PDA yang telah dicampur dengan larutan ekstrak lengkuas sesuai dengan konsentrasi. Inokulum yang ditanam berupa lempengan berrdiameter 0,5 $\mathrm{cm}$ dengan menggunakan pengebor gabus. Media tumbuh cawan petri yang berisi 
inokulum kemudian dipasangkan plastik anti panas agar tidak terkontaminasi.

Hasil analisa pada Tabel 1 memperlihatkan bahwa perlakuan yang menunjukan adanya perbedaan yang sangat signifikan adalah pada perlakuan kontrol, untuk perlakuan dengan konsentrasi 20\% terhadap 30\% terdapat perbedaan yang tidak signifikan, perlakuan dengan konsentrasi $30 \%$ terhadap $40 \%$ terdapat perbedaan yang signifikan, perlakuan dengan konsentrasi $40 \%$ terhadap $50 \%$ terdapat adanya perbedaan yang signifikan. Sedangkan perlakuan dengan konsentrasi 50\%, 60\%, $70 \%$ dan $80 \%$ tidak terdapat perbedaan, karena pada perlakuan dengan konsentrasi $50 \%, 60 \%, 70 \%$ dan $80 \%$ tidak terjadi pertumbuhan pada jamur Alternaria sp. hal ini disebabkan bahwa kandungan senyawa aktif yang terkandung pada ekstrak lengkuas mampu menghambat pertumbuhan jamur

\section{HASIL DAN PEMBAHASAN}

Alternaria sp.. Pada (Gambar 1) menunjukan persentase penghambatan berbanding lurus dengan konsentrasi perlakuan. Bahwa ekstrak lengkuas (Alpinia purpurata K. Schum) dengan konsentrasi $60 \%$ dapat menghambat pertumbuhan jamur Alternaria sp. dengan kematian jamur sebesar 79\%, berikut adalah tabel dan gambar persentase kematian pertumbuhan Alternaria sp..

Tabel 1. Uji Mann-Whitney Signifikansi Perbedaan Diameter Pertumbuhan

\begin{tabular}{cccccc}
\hline \hline \multirow{2}{*}{ Perlakuan } & $\mathrm{N}$ & \multicolumn{4}{c}{ Pada taraf $=0.05$} \\
& & 1 & 2 & 3 & 4 \\
\hline Kontrol & 3 & 0.050 & & & \\
$20 \%$ & 3 & & 0.261 & & \\
$30 \%$ & 3 & & 0.268 & & \\
$40 \%$ & 3 & & & 0.317 & \\
$50 \%$ & 3 & & & & 1.000 \\
$60 \%$ & 3 & & & & 1.000 \\
$70 \%$ & 3 & & & 1.000 \\
$80 \%$ & 3 & & & 1.000 \\
\hline \hline
\end{tabular}

Sumber: Data Primer Penelitian

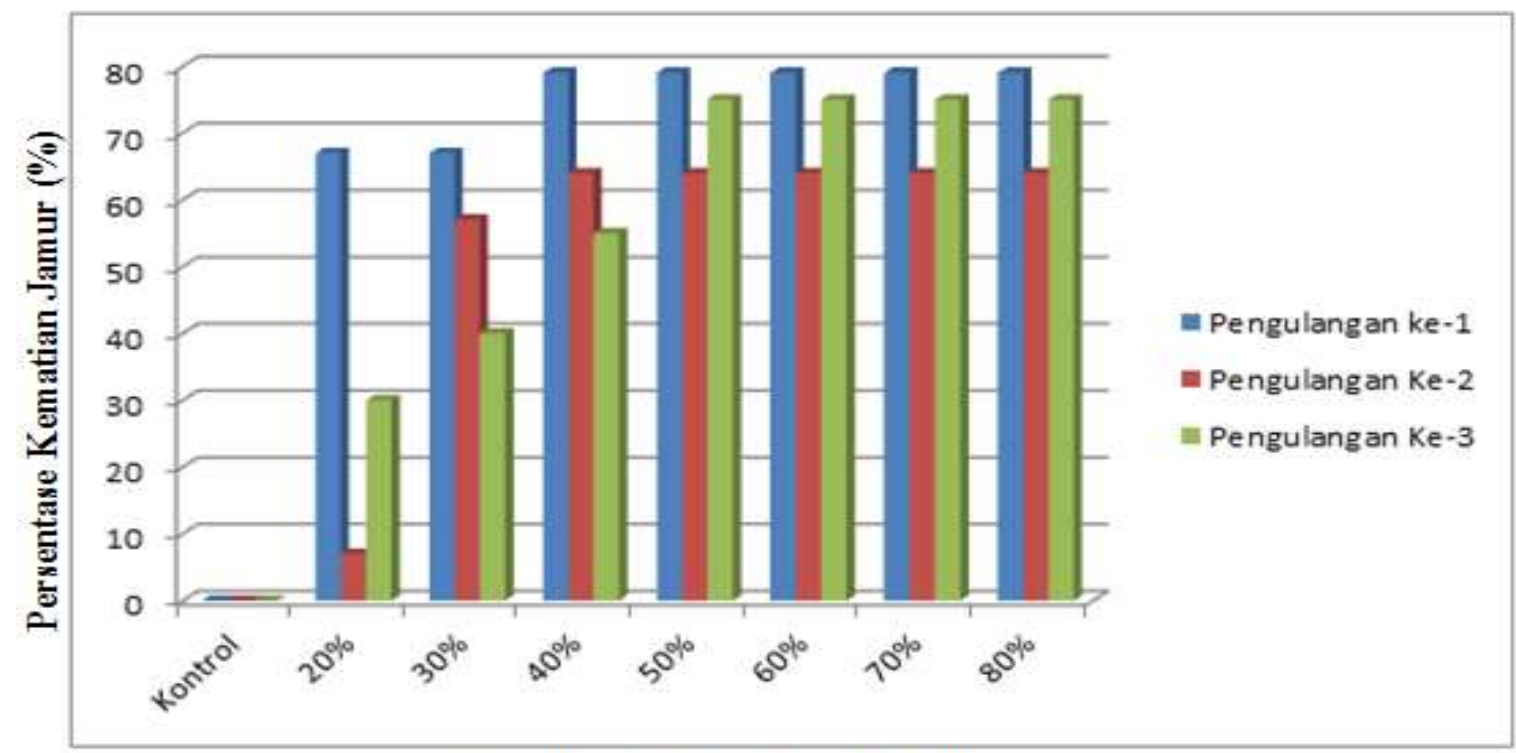

Perlakuan Ekstrak Lengkuas

Gambar 1. Persentase kematian jamur Alternaria sp. pada media tumbuh perlakuan. 
Senyawa aktif lengkuas merah (Alpinia purpurata K. Schum) pada konsentrasi 50\% mampu menunjukan respon terhadap penekanan pertumbuhan jamur Alternaria sp. akan tetapi pada konsentrasi $60 \%$ sudah terlihat kematian jamur Alternaria sp. pada seluruh koloni, artinya pada konsentrasi $60 \%$ ekstrak lengkuas dapat menghambat pertumbuhan jamur Alternaria sp. dengan kematian jamur sebesar 79\%. Hal ini disebabkan ekstrak lengkuas yang berdifusi ke dalam sel jamur semakin meningkat sehingga dapat menyebabkan terganggunya pertumbuhan jamur Alternaria sp. bahkan sampai menyebabkan kematian.

Penelitian ini dilakukan terhadap penghambatan pertumbuhan jamur Alternaria sp. secara in vitro dimana jamur tersebut merupakan salah satu penyebab penyakit yang menyerang tanaman jeruk seperti bunga atau buah yang akhirnya akan membusuk. Seperti yang dikatakan oleh (Ferniah et al. 2012) menjelaskan bahwa Alternaria sp. dikenal sebagai bakteri yang dapat menyebabkan timbulnya bercak pada beberapa daun. Alternaria $s p$. bisa tumbuh koloni tebal yang biasanya hitam atau abuabu. Setidaknya 20\% dari pembusukan pertanian disebabkan oleh spesies Alternaria $s p$. Berdasarkan penelitian lain menurut Ellis, 1971 dalam (Meena et al. 2010) mengatakan bahwa Alternaria sp. adalah parasit pada tanaman hidup atau saprofit pada substrat organik. Rentang patogen inang Alternaria sangat luas, mudah untuk mengenali
Alternaria sp. dengan morfologi konidia besar, dibentuk dalam rantai atau soliter, biasanya oval, coklat pucat sampai coklat, bersel banyak dan muriform.

Berdasarkan hasil penelitian ini ternyata kandungan senyawa aktif yang terkandung pada ekstrak lengkuas mampu menghambat pertumbuhan jamur Alternaria sp., senyawa aktif lengkuas merah (Alpinia purpurata K. Schum) pada konsentrasi 50\% menunjukan respon terhadap penekanan pertumbuhan jamur Alternaria sp., akan tetapi pada konsentrasi $60 \%$ sudah terlihat kematian jamur Alternaria sp. pada seluruh koloni, artinya pada konsentrasi $60 \%$ dapat menghambat pertumbuhan jamur Alternaria sp. dengan kematian jamur sebesar 79\%. Hal ini disebabkan ekstrak lengkuas yang berdifusi ke dalam sel jamur semakin meningkat sehingga dapat menyebabkan terganggunya pertumbuhan jamur Alternaria sp. bahkan sampai menyebabkan kematian.Seperti yang dikatakan oleh (Languas et al. 2012) dalam penelitiannya mengatakan bahwa hasil terbaik ditunjukkan oleh perlakuan lengkuas dengan konsentrasi $50 \%$ yang mampu mengendalikan pertumbuhan jamur Pythium sp. dengan kematian jamur sebesar $64 \%$ pada hari pertama dan menurun menjadi $60 \%$ pada hari kedua dan 54\% pada hari ketiga. Ekstrak lengkuas menunjukkan kemampuan yang lebih baik dibandingkan dengan jenis ekstrak lainnya dengan ditunjukkan oleh tingkat 
pengendalian pertumbuhan jamur Pythium sp. sebesar $64 \%$.

Berdasarkan hal tersebut, bahwa senyawa aktif yang terkandung pada esktrak lengkuas dapat membunuh jamur Alternaria $s p$. , seperti yang dikatakan oleh penelitianpenelitian sebelumnya menurut Gholib (2009) dalam penelitian (Languas et al. 2012) mengatakan bahwa senyawa aktif yang dihasilkan melalui ekstraksi etanol tersebut yang berperan dalam pengen-dalian fungi antara lain adalah minyak atsiri, flavonoid, saponin dan methyl-p-methoxy-cinnamate, methylcinnamate, carvone, eucalyptol dan pentadecane. Kemudian menurut (Chauhan Vimal Singh, Swapna M 2014) mengatakan bahwa rimpang lengkuas menunjukkan sifat anti mikroba terhadap bakteri, parasit, ragi dan jamur. Selain itu masih pada penelitian lain mengatakan bahwa zat yang bersifat anti mikroba pada lengkuas adalah flavanoid, fenol, terpenoid asetoksi-cavikol, asetat, dan minyak atsiri lainnya (Yuharmen, dkk 2002 dalam (Sitepu, Suada, and Susrama 2012).

Berbeda pada perlakuan dengan konsentrasi di bawah 50\% yaitu 20\%, 30\% dan $40 \%$ tidak mampu mengendalikan pertumbuhan jamur Alternaria sp., diamana pada konsentrasi 20\% kematian jamur sebesar 30\%, sedangkan pada perlakuan $30 \%$ kematian jamur sebesar $57 \%$ dan pada perlakuan dengan konsentrasi 40\% kematian jamur sebesar 64\%, hal ini disebabkan karena pada konsentrasi tersebut kandungan senyawa aktif yang terkandung sudah semakin berkurang saat berdifusi ke dalam sel jamur akibat dilakukannya pengenceran hingga mendapat konsentrasi yang diinginkan yaitu 20\%, 30\% dan $40 \%$ sehingga jamur Alternaria sp. masih tetap tumbuh seperti pada perlakuan kontrol bahkan terkontaminasi oleh mikroba lain tetapi tidak terlalu besar karena masih mengan-dung senyawa aktif ekstrak lengkuas walaupun kandungannya tidak tinggi seperti pada konsen-trasi 50\%, 60\%, 70\% dan $80 \%$. Berbeda pada perlakuan kontrol, jamur Alternaria $s p$. dapat tumbuh cenderung lebih besar dan terlihat lebih banyak juga terkontaminasinya oleh mikroba lain seperti jamur jenis lain maupun bakteri, karena pada kontrol tidak sama sekali diberi ekstrak lengkuas yang memang mengandung senyawa aktif lengkuas yang dapat menghambat pertum-buhan jamur.

Didapatkannya mikroba lain dalam penelitian ini diduga disebabkan oleh beberapa faktor seperti pada saat proses penelitian adanya spora jamur lain yang hinggap pada media perlakuan, kurangnya sterilisasi tempat atau alat pada saat menginokulasikan miselium jamur, kurang memperhatikan kondisi lingkungan sekitar yang memang dipakai juga oleh peneliti lain pada jenis jamur lain, kurang rekat pada saat mengikatkan karet pada plastik tahan panas dalam proses inkubasi. Terlepas dari hal tersebut, penelitian ini sudah dapat dikatakan bahwa pada ekstrak rimpang lengkuas dapat 
menghambat pertum-buhan jamur Alternaria sp..

Berdasarkan pada pemaparan tersebut bahwa setiap adanya penambahan konsentrasi pada ekstrak lengkuas memperlihatkan tidak adanya pertumbuhan jamur Alternaria sp.. Artinya semakin tinggi konsentrasi ekstrak lengkuas yang diberikan maka, semakin baik untuk menghambat pertumbuhan jamur Alternaria sp.. Seperti yang dikatakan oleh (Languas et al. 2012) dalam penelitiannya mengatakan bahwa semakin tinggi konsentrasi ekstrak lengkuas yang diberikan maka kemampuan mengendalikan pertumbuhan Pythium $s p$. semakin baik.

Pemanfaatan ekstrak lengkuas pada penelitian ini dapat digunakan pada perlakuan anti jamur Alternaria sp. karena potensi anti jamur hayati yang dimilikinya serta pemanfaatan bahan alami ini akan bersifat aman untuk lingkungan. Berdasarkan hal tersebut bahwa ekstrak lengkuas dapat digunakan sebagai bahan alternatif penggunaan pestisida khususnya pada fungisida dari fungisida sintetik yang sering digunakan oleh para petani. Seperti yang dikatakan oleh (Idris and Nurmansyah 2016) pada penelitiannya mengatakan bahwa salah satu pilihan atau alternatif lain untuk mengendalikan penyakit tanaman dari penggunaan pestisida sintetik adalah menggunakan pestisida nabati.

Berdasarkan pembahasan diatas yang telah dipaparkan maka, hipotesis pada penelitian ini dapat diterima, yaitu ekstrak lengkuas (Alpinia purpurata K. Schum) berpotensi sebagai fungisida untuk mengendalikan pertumbuhan jamur Alternaria sp. pada tanaman jeruk (Citrus Spp.). Selain dapat menjawab hipotesis, peneli-tian ini juga dapat digunakan sebagai acuan bahan pembelajaran kepada siswa, mahasiswa ataupun kepada masyarakat luas dengan memanfaatkan tanaman kembali bagi perkembangan lingkungan atau kelangsungan kehidupan pada masyarakat.

\section{KESIMPULAN}

Ekstrak lengkuas menunjukan kemampuan me-ngendalikan pertumbuhan jamur Alternaria sp., ini ditunjukan oleh tingkat pengendalian pertum-buhan jamur Alternaria sp. pada perlakuan konsentrasi $60 \%$ dengan kematian jamur sebesar $79 \%$. Semakin tinggi konsentrasi ekstrak yang di berikan, kemampuan mengendalikan pertumbuh-an jamur Alternaria sp. semakin baik. Pada percobaan ini ekstrak lengkuas dapat digunakan sebagai bahan alternatif penggunaan pestisida khususnya pada fungisida dari fungisida sintetik yang sering digunakan oleh para petani, karena potensi antijamur hayati yang dimilikinya serta pemanfaatan bahan alami ini akan bersifat aman untuk lingkungan. Penelitian ini juga dapat digunakan sebagai acuan bahan pembelajaran kepada siswa, mahasiswa ataupun kepada masyarakat luas dengan memanfaatkan tanaman kembali bagi 
perkembangan lingkungan atau

kelangsungan kehidupan pada masyarakat.

\section{DAFTAR PUSTAKA}

Chauhan Vimal Singh, Swapna M, and Ajith Singh. $2014 . \quad$ "Phytochemical Investigation And Cytotoxic Activity Of Methanolic Extract Of Alpinia Galanga Department Of Pharmacology , Vidhya Bharathi College Of Pharmacy, Bitu , Rourkela, Odisha , India , Materials And Methods Plant Material Isolation Method." International Journal of Applied Biology and Pharmaceutical Technology 5 (3): 186-89.

Ferniah, Rejeki Siti, Sri Pujiyanto, Susiana Purwantisari, and Supriyadi Supriyadi. 2012. "Interaksi Kapang Patogen Fusarium Oxysporum Dengan Bakteri Kitinolitik Rizosfer Tanaman Jahe Dan Pisang." Jurnal Natur Indonesia 14 (1): 56. https://doi.org/10.31258/jnat.14.1.5660.

Idris, Herwita, and Nurmansyah Nurmansyah. 2016. "Efektivitas Ekstrak Etanol Beberapa Tanaman Obat Sebagai Bahan Baku Fungisida Nabati Untuk Mengendalikan Colletotrichum Gloeosporioides." Buletin Penelitian Tanaman Rempah Dan Obat 26 (2): 117. https://doi.org/10.21082/bullittro.v26 n2.2015.117-124.

Languas, Lengkuas, L Stunz, Terhadap Pythium, Ujang W Darmawan, and Illa Anggraeni. 2012. "Pengaruh Ekstrak Rimpang Kunyit (Curcuma Domestica Val .), Kaempferia Galanga L . Rhizome Extract on Pythium Sp .)," 135-40.

Meena, P D, R P Awasthi, C Chattopadhyay, S J Kolte, and Arvind Kumar. 2010. "Alternaria Blight: A Chronic Disease in Rapeseed-Mustard." Journal of Oilseed Brassica 1 (1): 1-11.

Sitepu, Irma Selvyana, I Ketut Suada, and I Gede Ketut Susrama. 2012. "Uji Aktivitas
Antimikroba Beberapa Ekstrak Bumbu Dapur Terhadap Pertumbuhan Jamur Curvularia Lunata (Wakk.) Boed. Dan Aspergillus Flavus Link." E-Jurnal Agroekoteknologi Tropika Uournal of Tropical Agroecotechnology) 1 (2): 10714.

Sugiyono. 2016. Metode Penelitian Kuantitatif, Kualitatif, Dan R\&D. Bandung: Alfabeta. 